\title{
Progesterone in Peri- and Postmenopause: A Review
}

\section{Progesteron in der Peri-und Postmenopause - ein Überblick}

Author

Affiliations
P.-A. Regidor ${ }^{1,2}$

${ }^{1}$ Praxis für Frauenheilkunde, München

2 Velvian $\mathrm{GmbH}$, Ismaning
Key words

- hormone therapy

- progesterone

- menopause

- menopausal symptoms

Schlüsselwörter

- Hormontherapie

- Progesteron

- Menopause

- Wechseljahresbeschwerden

Deutschsprachige Zusatzinformationen online abrufbar unter: www.thieme-connect.de/ ejournals/toc/gebfra

\begin{abstract}
received 27.1.2014 revised $\quad 1.10 .2014$ accepted $\quad 1.10 .2014$
\end{abstract}

\section{Bibliography}

DOI http://dx.doi.org/ 10.1055/s-0034-1383297

Geburtsh Frauenheilk 2014; 74: 995-1002 @ Georg Thieme Verlag KG Stuttgart · New York ISSN 0016-5751

\section{Correspondence}

Pedro-Antonio Regidor,

MD PhD

Praxis für Frauenheilkunde

Bauberger Straße 16

80992 München

regidor@t-online.de

\section{Abstract \\ $\nabla$}

Around 14.5 million peri- and postmenopausal women currently live in Germany. Moreover, approximately 450000 women, each with a life expectancy of around 85 years, reach menopause every year in Germany. The challenge is therefore to find a therapy with few side effects which could improve the quality of life of women with menopausal symptoms. The aim of hormone therapy (HT) is to remedy hormone deficiencies using substances that offer the best trade-off between benefits and risks. This is where progesterone has a new and important role to play. Progesterone is one of the most important gestagens. Biologically effective progesterone formulations created with micronization techniques have been used in clinical practice since 1996. Nevertheless, up until 2003 preference was given to synthetic gestagens rather than progesterone. The increased breast cancer hazard ratio of 1.23 reported in the WHI study and of 2 given in the Million Women Study has been associated with the use of synthetic gestagens. In a comparison between synthetic gestagens and progesterone, the E3N Study showed that the transdermal administration of estrogen and progesterone did not lead to an increase in breast cancer rates (RR: 1.08). The administration of progesterone does not change the HDL/LDL cholesterol ratio. Because of its anti-mineralocorticoid effect, progesterone has no impact on carbohydrate metabolism, hemostasis, blood pressure, thrombogenicity and body weight. The administration of $200 \mathrm{mg} /$ day progesterone over 12 days of a menstrual cycle or a daily administration of $100 \mathrm{mg}$ combined with an estrogen are a safe and well-tolerated option to treat menopausal symptoms, with a better benefit risk profile compared to synthetic gestagens.

\section{Zusammenfassung \\ $\nabla$}

Aktuell leben 14,5 Millionen peri- und postmenopausale Frauen in Deutschland. Gleichzeitig gibt es ungefähr 450000 neue menopausale Frauen pro Jahr, die eine Lebenserwartung von bis zu 85 Jahren haben. Die Herausforderung besteht daher in einer möglichst nebenwirkungsarmen Therapie bei den Frauen mit menopausalen Beschwerden, um einer Verschlechterung ihrer Lebensqualität entgegenzuwirken. Ziel einer Hormontherapie (HT) sollte die Behebung des Hormonmangels sein, wobei Substanzen mit dem besten Nutzen-Risiko-Profil eingesetzt werden sollten. Hier spielt Progesteron eine neue und wichtige Rolle. Beim Progesteron handelt es sich um den wichtigsten Vertreter der Gestagene. Durch Mikronisierungsverfahren können biologisch wirksame Formulierungen hergestellt werden, sodass es seit 1996 Anwendung im klinischen Alltag findet. Dennoch wurde bis 2003 den synthetischen Gestagenen und nicht dem Progesteron der Vorzug gegeben. Die Erhöhungen des Mammakarzinomrisikos in der WHI-Studie auf eine Ratio von 1,23 und in der Million-Women-Studie auf bis zu 2 sind daher auch unter diesem Aspekt zu werten. Beim Vergleich zwischen synthetischen Gestagenen und Progesteron konnte in der E3N-Studie gezeigt werden, dass es unter einer transdermalen Östrogengabe zusammen mit Progesteron nicht zu einer Erhöhung der Mammakarzinomrate (RR von 1,08) kommt. Progesteron verändert nicht die HDL/LDL-Cholesterinratio. Es hat keinen Einfluss auf den Kohlenhydratstoffwechsel, die Hämostase, den Blutdruck, die Thrombogenität und das Körpergewicht, da es auch antimineralokortikoid wirkt. Die Gabe von $200 \mathrm{mg}$ Progesteron pro Tag über 12 Tage im Zyklus oder die tägliche Gabe von 100 mg in Kombination mit einem Östrogen stellen daher eine sichere Option in der Behandlung der menopau- 
salen Beschwerden dar, bei gleichzeitig besserem Nutzen-RisikoProfil als die synthetischen Gestagene.

\section{Introduction}

Investigations into the physiological effects of progesterone started at the beginning of the 20th century [1]. The destruction of the ovarian corpus luteum was found to result in abortion in pregnant animals. This could be prevented if animals were given an injection of corpus luteum extract. A number of research groups, working independently, finally managed to isolate progesterone from corpus luteum extract in 1934. The substance was first known as progestin in the USA and as luteosterone in Europe. In 1935 scientists agreed to name it progesterone as an indication that this hormone plays in important role in pregnancy (pro gestationem [Latin]: i.e., favoring gestation) [2,3]. In the mid-1940s, Russell Marker managed to synthesize large amounts of pure progesterone from diosgenin, which could be sourced from plants. However, very high oral doses were necessary to obtain biological effects. Advances in galenical formulation, particularly in micronization techniques, improved the resorption property of progesterone, and after 1980 oral therapy using natural progesterone was possible [4,5].

Progesterone is a steroid with 21 carbon atoms. In the human body it is produced in syncytiotrophoblasts and luteinized granulosa cells of the ovarian follicles, in the cortical fascicles and the retinal areas of the adrenal cortex.

Precursors of progesterone include LDL, VLDL, HDL and cholesterol synthesized de novo (VDL: very low density lipoprotein). Around 95-98\% of progesterone in blood is protein-bound, with most of it bound to serum albumin. Oral administration increases plasma levels of progesterone metabolites, primarily of pregnandiol, pregnanolone (dihydroprogesterone), pregnandione, 20- $\alpha$ dihydroprogesterone and 17-OH-progesterone [6-8]. 5- $\alpha$-hydroxysteroid dehydrogenase converts metabolic intermediates to allopregnanolone, an important neuroactive steroid $[9,10]$. Progesterone has both systemic and local effects. At the systemic level, progesterone increases diuresis through activation of the renin-angiotensin system, triggers the catabolic metabolism, relaxes smooth muscle cells, increases excretion of calcium and phosphorus, raises basal body temperature, has sedative and analgesic effects, improves visual memory and the proliferation and differentiation of osteoblasts and has additionally been found to have an immunosuppressive effect [11]. For a long time, however, the established opinion was that oral administration of progesterone had only limited efficacy, as its bioavailability was strongly reduced due to the hepatic first-pass effect [12]. This led to the use of synthetic gestagens such as derivatives of testosterone or 17-hydroxyprogesterone, as they are more resistant to hepatic degradation. But synthetic gestagens are associated with significant side effects due to their anti- or pro-estrogen effects, anti- or pro-androgen effects, mineralocorticoid effects and negative effects on glucose metabolism and lipid metabolism [13]. Advances in micronization and the suspension of progesterone in oil solutions has led to new data, which has demonstrated the bioavailability of orally administered progesterone [13]. Simon et al. additionally showed that the highest serum levels were obtained when oral progesterone preparations were taken together with food [14].
Progesterone effects a number of changes in the reproductive system and the mammary glands, which have important implications for its potential therapeutic use. Effects include

1. transition of the endometrium from the proliferative to the secretory phase [15]

2. preparation of the endometrium for potential implantation $[16,17]$

3. maintaining pregnancy [18]

4. the reduction of uterine muscular activity through the development of increased numbers of $\beta$-adrenergic receptors and the reduction of sensitivity to oxytocin [19-21]

5. the reduction of prostaglandin synthesis [22]

6 . stimulating the development of lobuli and mammary ducts in breast tissue $[23,24]$.

7. High levels of progesterone during pregnancy serve to prepare the mammary glands for lactation [25].

These effects indicate a number of areas where progesterone administration could be beneficial.

\section{Indications for Progesterone Administration}

$\nabla$

There are currently a number of well-known indications for progesterone administration, both in gynecology and obstetrics. These include

- primary or secondary amenorrhea [26]

- infertility due to known corpus luteum insufficiency [27]

- treatment of endometriosis $[28,29]$

- treatment of fibrocystic mastopathy [30]

- treatment of premenstrual syndrome [31]

- supporting the luteal phase during IVF treatment (IVF: in vitro fertilization) [32]

- prevention of pregnancy loss [33]

- protection of the endometrium during HT with estrogen [3444]

Several studies have recently shown that micronized progesterone is tolerated better than synthetic gestagens [35-37].

Progesterone plays a very important role for the endometrium, primarily in the implantation and development of the fertilized ovum. It is significantly involved in the proliferative to secretory transition of the endometrium, the decidualization of the endometrium, in triggering the synthesis of PAPP-A (pregnancy-associated plasma protein A), PP14 (placental protein 14) and uteroglobin, the development of PIBF (progesterone-induced blocking factor), the switch from Th1 to Th2 cells (Th cells: T helper cells), the stimulation of prostaglandin E2 production and suppression of the matrix metalloproteinases MMP3 and MMP9 [38]. All these factors are essential parts of normal development during pregnancy.

In the breast, progesterone causes down-regulation of estrogen receptors and inhibits estrogen-induced proliferation of epithelial cells [39]. After initial stimulation progesterone can arrest human cancer cell growth in the late G1 phase (G: gap) of the 2nd cycle [40]. In a study using breast tissue obtained by fine-needle aspiration biopsy it was found that normal increases in progesterone during the luteal phase results in down-regulation of estrogen receptors but not of progesterone receptors. This points to an important anti-estrogen and anti-proliferative effect in 
breast epithelial cells [41]. Other studies have confirmed that cell proliferation depends directly on the estrogen-progesterone ratio in breast tissue and is lower in the luteal phase than in the follicular phase [42]. This means that progesterone exerts an overall protective effect on breast tissue. Additional factors which reinforce this protective effect include an apoptosis-inducing effect together with the inhibition of $17 \beta$-HSD (hydroxysteroid dehydrogenase) reductive activity in breast tissue, which is particularly active in breast cancers $[43,44]$.

\section{Progesterone in Peri- and Postmenopause}

Various effects of progesterone administration in peri- and postmenopause are summarized below.

\section{Effects on the endometrium}

Although the oral bioavailability of progesterone is not high, the PEPI trial convincingly demonstrated that progesterone offers endometrial protection in women receiving estrogens to treat menopausal symptoms. This placebo-controlled trial investigated the efficacy of micronized progesterone for the prevention of endometrial hyperplasia and compared a placebo group with 2 different MPA administration regimens (MPA: medroxyprogesterone acetate). Micronized progesterone, administered once daily for 12 days prior to going to bed was found to protect the endometrium from hyperplastic changes associated with estrogen-only therapy as effectively as the two MPA therapies [34] ( $\triangle$ Table 1). Similar data on endometrial protection were presented previously by Lalumiere and colleagues [45]. They also showed that women who received micronized progesterone had significantly fewer bleeding episodes and shorter bleeding than the control group who received MPA. In this study the patients also received $200 \mathrm{mg}$ progesterone for 12 days in every cycle.

In a 2001 study of 336 women with early menopause, Pélissier et al. [46] also found that micronized progesterone provided effective endometrial protection. In their study, one group received transdermal estrogen plus chlormadinone acetate $10 \mathrm{mg} /$ day and the other group received transdermal estrogen plus $200 \mathrm{mg}$ progesterone for 14 days. Around one third of the women who received micronized progesterone had amenorrhea after 6 and 18 months. Overall bleeding status was more stable with progesterone than with chlormadinone acetate ( $\boldsymbol{O}$ Fig. $\mathbf{1}$ ).

As the transformation dose for progesterone is $2000 \mathrm{mg}$ per cycle, patients should receive either $100 \mathrm{mg} /$ day continuously or $200 \mathrm{mg} /$ day sequentially for a period of $12-14$ days every cycle to ensure satisfactory secretory transformation of the endometrium in women previously treated with estrogens [47].

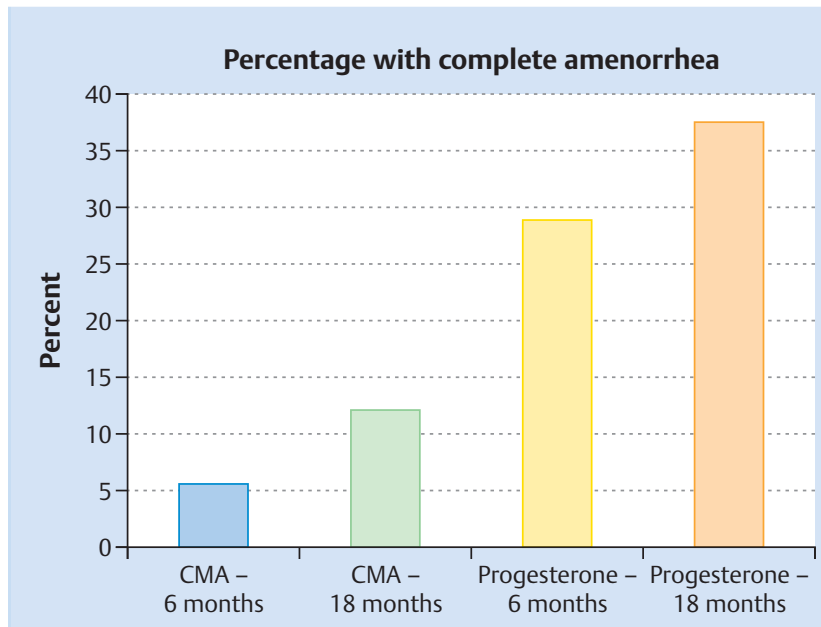

Fig. 1 Amenorrhea after 6 and 18 months receiving either $10 \mathrm{mg}$ chlormadinone acetate or $200 \mathrm{mg}$ progesterone administered cyclically for 14 days [46]. CMA: chlormadinone acetate.

\section{Effect on the breast}

Since the publication of the WHI study [48] HT in menopause has been associated with increased rates of breast cancer. Both the data of the WHI study and the results of the Million Women Study [49] led at the beginning of 2000 to an abrupt drop in hormone treatments for menopausal symptoms.

The association was also reported for animal experiments [50]: long-term administration of estradiol and progesterone had a promotional effect on breast cancer after treatment with carcinogenic substances or spontaneously.

Investigations of breast cancer cell lines showed that high concentrations of progesterone had an antiproliferative (pro-apoptotic) effect, but that the reverse effect was obtained with low MPA concentrations. Synthetic gestagens such as MPA or norethisterone alone or in combination with estrogens can stimulate breast cancer cells in vitro. However, progesterone alone or in combination with estrogens had an antiproliferative or neutral effect [51-53]. In a quantitative mouse model, Otto et al. [54] showed that the same dose of MPA had a proliferative effect on breast tissue and an inhibitory effect on the uterus, while no such association was found for progesterone. A twofold higher dose of progesterone was required to induce proliferative effects in breast tissue compared to the doses which resulted in complete inhibition of estradiol-activated endometrial proliferation. It appears therefore that progesterone administration is associated with a beneficial safety margin between the desirable inhibition

Table 1 Results of the endometrial biopsies at the end of the trial [34].

\begin{tabular}{|lccccc}
\hline Results & Placebo & CEE alone & $\begin{array}{l}\text { CEE + } \\
\text { cyclic MPA }\end{array}$ & $\begin{array}{l}\text { CEE + } \\
\text { cont. MPA }\end{array}$ & $\begin{array}{l}\text { CEE + micronized } \\
\text { progesterone }\end{array}$ \\
Normal & 116 & 45 & 112 & 119 & 114 \\
\hline Simple (cystic) hyperplasia & 1 & 33 & 4 & 0 & 5 \\
\hline Complex (adenomatous) hyperplasia & 1 & 27 & 2 & 0 & 0 \\
\hline Atypical hyperplasia & 0 & 14 & 0 & 0 & 1 \\
\hline Adenocarcinoma & 1 & 0 & 0 & & 0 \\
\hline
\end{tabular}

CEE: conjugated equine estrogens; MPA: medroxyprogesterone acetate; cont.: continuous 
Table 2 Progesterone and synthetic gestagens and their properties (mod. nach [73].

\begin{tabular}{|c|c|c|c|c|c|c|c|c|}
\hline & $\begin{array}{l}\text { Proges- } \\
\text { togenic }\end{array}$ & $\begin{array}{l}\text { Anti- } \\
\text { gonado- } \\
\text { tropic }\end{array}$ & $\begin{array}{l}\text { Anti- } \\
\text { estro- } \\
\text { genic }\end{array}$ & $\begin{array}{l}\text { Estro- } \\
\text { genic }\end{array}$ & $\begin{array}{l}\text { Andro- } \\
\text { genic }\end{array}$ & $\begin{array}{l}\text { Anti- } \\
\text { andro- } \\
\text { genic }\end{array}$ & $\begin{array}{l}\text { Gluco- } \\
\text { corticoid }\end{array}$ & $\begin{array}{l}\text { Antimineralo- } \\
\text { corticoid }\end{array}$ \\
\hline Progesterone & + & + & + & - & - & \pm & + & + \\
\hline Dydrogesterone & + & - & + & - & - & \pm & - & \pm \\
\hline Medrogestone & + & + & + & - & - & \pm & - & - \\
\hline \multicolumn{9}{|c|}{ 17a-Hydroxyprogesterone derivatives } \\
\hline Chlormadinone acetate & + & + & + & - & - & + & + & - \\
\hline Cyproterone acetate & + & + & + & - & - & ++ & + & - \\
\hline Megestrol acetate & + & + & + & - & \pm & + & + & - \\
\hline Medroxyprogesterone acetate & + & + & + & - & \pm & - & + & - \\
\hline \multicolumn{9}{|l|}{ 19-Nor-progesterone derivatives } \\
\hline Nomegestrol acetate & + & + & + & - & - & \pm & - & - \\
\hline Promegestone & + & + & + & - & - & - & - & - \\
\hline Trimegestone & + & + & + & - & - & \pm & - & \pm \\
\hline \multicolumn{9}{|l|}{ 19-Nortestosterone derivatives } \\
\hline Norethisterone & + & + & + & + & + & - & - & - \\
\hline Lynestrenol & + & + & + & + & + & - & - & - \\
\hline Norethynodrel & \pm & + & + & + & + & - & - & - \\
\hline Levonorgestrel & + & + & + & - & + & - & - & - \\
\hline Norgestimate & + & + & + & - & + & - & - & - \\
\hline Desogestrel & + & + & + & - & + & - & - & - \\
\hline Gestoden & + & + & + & - & + & - & + & + \\
\hline Dienogest & + & + & \pm & \pm & - & + & - & - \\
\hline \multicolumn{9}{|l|}{ Spirolonactone derivatives } \\
\hline Drospirenone & + & + & + & - & - & + & - & + \\
\hline
\end{tabular}

of endometrial proliferation and undesirable epithelial cell proliferation in the mammary gland. No such safety margin was found for MPA. Murkes et al. [55] reported that treating postmenopausal women with $1.5 \mathrm{mg} /$ day estradiol in the form of a gel and $200 \mathrm{mg}$ progesterone administered orally for 14/28 days did not significantly increase epithelial cell proliferation in the breast compared to baseline values, while the administration of $0.625 \mathrm{mg} /$ day CEE (conjugated equine estrogen) plus $5 \mathrm{mg}$ MPA on 14 out of 28 days significantly increased proliferation. At the same time, the number of bcl-2-positive (bcl-2: B-cell lymphoma 2 ) breast cells was reduced, indicating an apoptotic effect at the end of the gestagen phase.

In recent years, the importance of mammographic density as a risk factor for the development of breast cancer has become increasingly clear [56]. In a case-control study, Heusinger et al. [57] showed that patients with breast cancer had a significantly higher mammographic density compared to women without disease. However, both the female breast and mammographic density is affected by many hormonal influences. Boyd et al. [58] showed that mammographic density increases with HT, while antiestrogen tamoxifen treatment decreases mammographic density. The impact of HT has also been confirmed by other study groups [59-61].

\section{Tolerability and Safety of Progesterone}

\section{$\nabla$}

As shown in Table 2, progesterone is associated with a number of partial side effects which clearly differentiate it from all synthetic gestagens. This profile outlines the individual effects on different parameters in the human body.

\section{Effect on glucose metabolism}

Several studies (PEPI, WHI and HERS trials [PEPI: Postmenopausal Estrogen/Progestin Interventions; HERS: Heart and Estrogen/ Progestin Replacement Study]) [34,48,62] have shown that nondiabetic postmenopausal women have significantly lower fasting blood glucose levels and even lower fasting insulin levels during oral estrogen or estrogen-gestagen treatment compared to placebo groups. The administration of progesterone is not expected to cause any relevant changes to glucose metabolism. The E3N Study [63] also showed that administration of transdermal estrogen with micronized progesterone significantly reduced the risk for diabetes, even over a significant period of exposure. In contrast to synthetic gestagens progesterone has no detrimental effect on glucose balance.

\section{Effect on blood pressure}

All existing studies on progesterone show that, in general, the effect of progesterone on blood pressure is neutral and it may even have a slightly antihypertensive effect. The PEPI trial found no increase in blood pressure in either the estrogen group or the estrogen/progesterone group compared to placebo-treated controls [64].

\section{Progesterone and body weight}

Both the PEPI trial [64] and the WHI Study showed [34,48] that postmenopausal HT-treated women had a lower body weight gain on average compared to women receiving no hormone therapy. The progesterone administered during the PEPI trial was also neutral with regard to body weight, suggesting that progesterone has no effect on this parameter. 


\section{Progesterone and Lipid Metabolism}

\section{$\nabla$}

Overall, estrogen therapy is associated with positive long-term effects (HDL-C levels [C: cholesterol] increase, LDL-C levels decrease) on the lipoprotein profile of postmenopausal women, although it should be noted that this effect was found more commonly for orally administered estrogen.

In contrast to these findings, synthetic gestagens if combined with estrogens reduce HDL-C concentrations. A direct comparison with synthetic gestagens (MPA, norethisterone or norgestrel) showed that micronized progesterone has fewer negative effects on HDL-C metabolites compared to synthetic gestagens. Saarikoski et al. [65] carried out a study in 80 perimenopausal women treated for functional menometrorrhagia. The women were divided into 2 groups to receive either $300 \mathrm{mg} /$ day oral micronized progesterone for 10 days per cycle or $15 \mathrm{mg}$ /day norethisterone for 10 days per cycle over 6 consecutive cycles. The study showed that HDL-C levels remained stable with progesterone, but there was marked decrease in HDL-C levels in the norethisterone group $(\mathrm{p}<0.001)$. The previously mentioned PEPI trial also showed that, in significant contrast to medroxyprogesterone used in the other arms of the study, progesterone has the least impact on the positive effect on HDL-C caused by estrogens [64] ( $\bullet$ Fig. 2).

\section{Progesterone and the CNS}

Progesterone exerts several effects on the central nervous system. Chief among these are a sedative effect, created by its metabolites, in particular $5 \alpha$ - and $5 \beta$-allopregnanolone. Doses of up to $1200 \mathrm{mg}$ have been trialed in various studies. It was found that patients subjectively described a feeling of fatigue but experienced no impairment of psychological or physical performance [66-68]. This phenomenon can be put to good use to treat postmenopausal women suffering from sleep disorders by administering progesterone in the evening. Here again an important difference was noted between progesterone and the synthetic gestagens: synthetic gestagens are not converted into the abovementioned metabolites and thus have no soporific effect. Schu-
HDL levels with different gestagens and progesterone (PEPI Study)

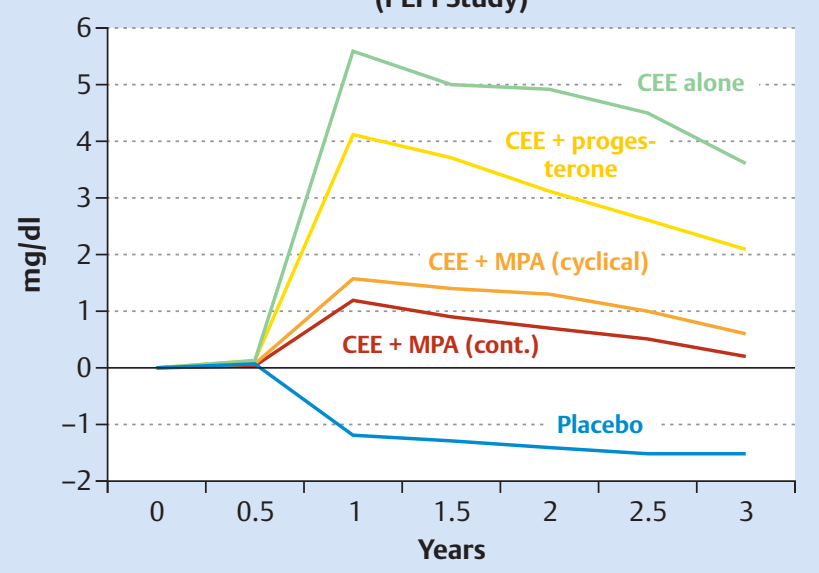

Fig. 2 Changes in HDL-C levels (HDL-C: lipoproteins with high density cholesterol) after estrogen monotherapy, estrogen and progesterone administration, cyclical administration of estrogen with MPA (medroxyprogesterone acetate), continuous administration of estrogen with MPA, and placebo (from the PEPI trial) [64]. CEE: conjugated equine estrogen.

macher et al. [69] reported that progesterone has neuroactive properties and can exert anxiolytic and antiepileptic effects in selected patients $[70,71]$.

\section{Safety of progesterone in hormone therapy}

The previously mentioned PEPI trial [34] was the first big study to use oral micronized progesterone to treat postmenopausal symptoms. In this 3-year, placebo-controlled prospective study, 875 non-hysterectomized postmenopausal women were randomized and divided into the following study arms: placebo for 28 days, $0.625 \mathrm{mg}$ CEE/day for 28 days, $0.625 \mathrm{mg}$ CEE plus $2.5 \mathrm{mg}$ medroxyprogesterone acetate either continuously or cyclically for the first 12 days, and $0.625 \mathrm{mg}$ CEE plus $200 \mathrm{mg}$ progesterone

\section{Relative risk (RR) for breast cancer Results of the E3N Study $(n=80377)$ : \\ Breast cancer RR according to HRT type \\ Reference group $=$ non-receivers $(R R=1)$}

Fig. 3 Breast cancer rates: results of the E3N Study [63]. MPA: Medroxyprogesterone acetate.

Results according to HRT type ( $n=2354$ women)

Oral estrogens with...

- Norethisterone acetate (46)

- Cyproterone acetate (34)

- MPA (29)

- Promegestone (13)

Transdermal estrogen with...

- Progesterone (121)

- Dydrogesterone (90)

- Nomegestrol acetate (91)

- Promegestone (69)

- Chlormadinone acetate (35)

- Medrogestone (28)

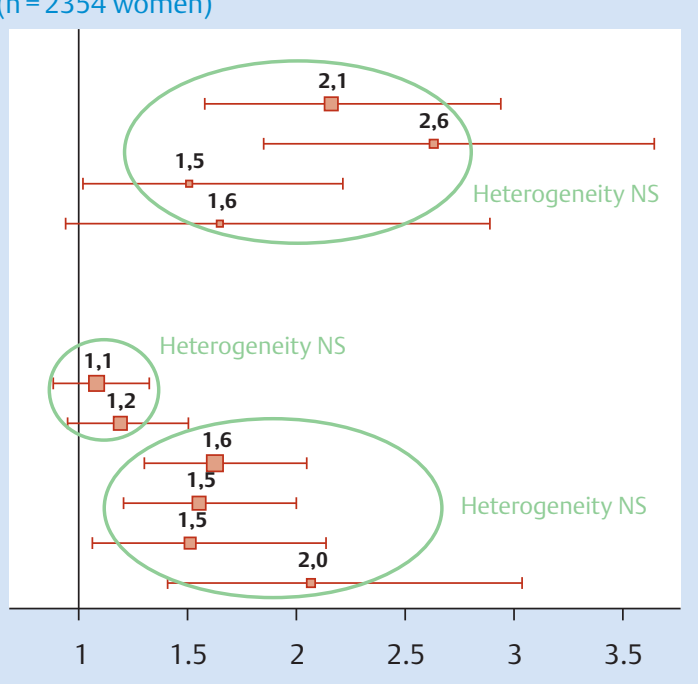


Thromboembolism risk with HRT - Results of the E3N Study

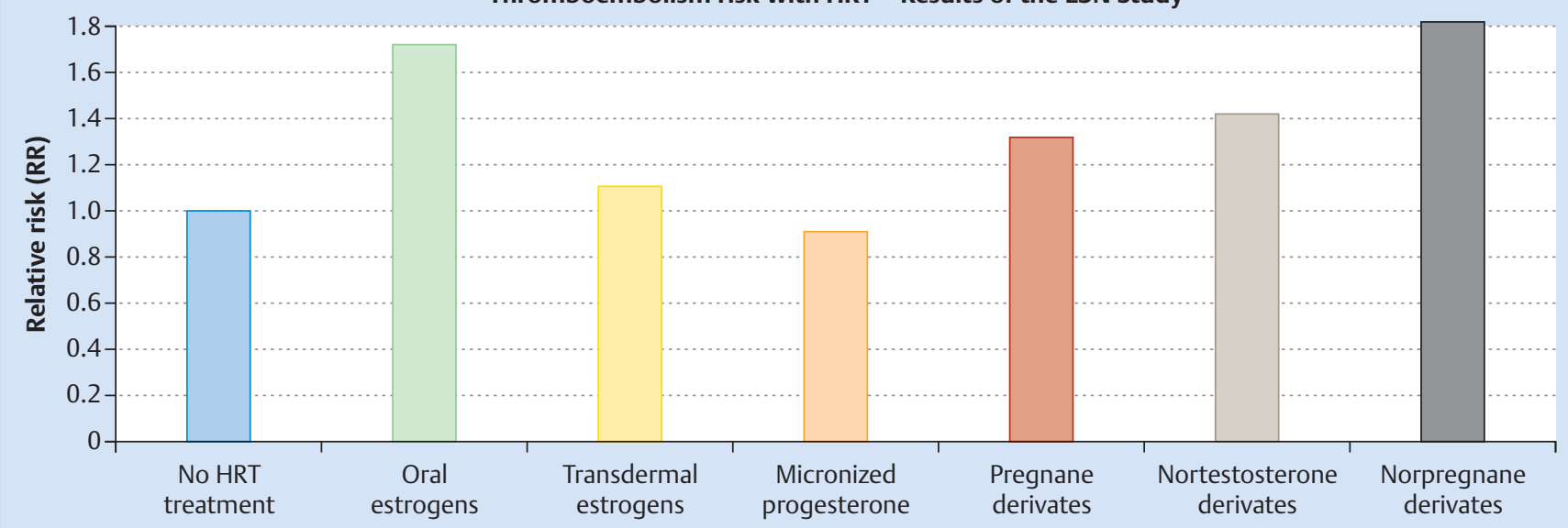

Fig. 4 Thromboembolism rates for different gestagens and progesterone in the E3N Study [63].

for the first 12 days. Endometrial biopsies were performed in 596 patients after the therapy to demonstrate the endometrial safety of HT. As expected, the rate of endometrial changes was highest in the group which had received CEE alone, while no significant endometrial pathologies were found in patients in the 3 study arms treated according to gestagen protocols ( 0 Table $\mathbf{1}$ ). The study investigated many additional parameters including subjective well-being, metabolic parameters, blood pressure, changes in body weight, etc. No negative effects were found in the group of women receiving progesterone. A much bigger study, the French E3N cohort study [63], collected data from more than 87000 postmenopausal women to assess the efficacy and safety with a particular focus on breast cancer and thromboembolism rates. A number of different gestagens were compared with micronized progesterone.

Breast cancer rates and thromboembolism rates did not increase after the administration of progesterone in HT in contrast to women who did not receive hormone treatment (odds ratio was 1.08 for breast cancer [ $\boldsymbol{\odot}$ Fig. 3 ] and 0.9 for thrombosis [ 0 Fig. 4]). The most recent publication of the KEEPS Reports (KEEPS: Kronos Early Estrogen Prevention Study) in 2011 not only reported positive effects of progesterone on cognitive functions but also described a protective effect for the cardiovascular system; at the same time, the risk of breast cancer was not increased in women receiving either placebo or $0.45 \mathrm{mg}$ CEE plus $200 \mathrm{mg}$ progesterone for 12 days or $50 \mu \mathrm{g}$ estradiol per day administered via a patch together with $200 \mathrm{mg}$ progesterone for 12 days. Rates for endometrial cancer, stroke, myocardial infarction and thromboembolism were also the same in all 3 groups [72].

The only absolute contraindications for progesterone administration in the narrower sense are rare autoimmune allergic reactions and anti-epileptic drugs or tuberculostatic agents as the intake of these drugs is associated with rapid hepatic degradation.

\section{Conclusion}

$\nabla$

Progesterone or corpus luteum hormone can be used safely and effectively to treat menopausal symptoms or for hormone substitution in menopausal women, as it constitutes a bio-identical preparation which can be used to correct deficiency symptoms.
Administration to achieve the necessary transformation dose for endometrial safety through progesterone can be either continuous ( $100 \mathrm{mg} /$ day) or cyclical ( $200 \mathrm{mg} /$ day) for $12-14$ days.

\section{Conflict of Interest}

$\nabla$

The author is medical director of the company Velvian $\mathrm{GmbH}$, a member of the Exeltis Group.

\section{References}

1 Williams CL, Stancel GM. Estrogens and Progestins. In: Goodman LS, Gilman A, eds. The pharmacological Basis of Therapeutics. 9th ed. Elmsford, Oxford: Pergamon Press; 1996: 1411-1440

2 Millart P, Paszkowski T. Progestageny w praktyee ginekologieznej. Ginekol Prakt 2002; 67: 16-21

3 Paszkowski T, Kozlowska J. Progesteron-druga mlodosc starego leku. Ginekol Prakt 2003; 70: 52-57

4 Loose DS, Stancel GM. Estrogens and Progestins. In: Brunton LL, eds. Goodman \& Gilman's the pharmacological Basis of Therapeutics. 11th edn. New York: McGraw-Hill; 2006: 1541-1571

5 Morville R, Dray F, Reynier J et al. Biodisponibilité de la progestérone naturelle administrée par voie orale. Mesure des concentrations du stéroide dans le plasma, l'endomêtre et le tissue mammaire. J Gynecol Obstet Biol Reprod 1982; 11: 355-363

6 Speroff L, Glass RH, Kase NL, eds. Clinical gynecologic Endocrinology and Infertility. Baltimore, Philadelphia: Lippincott Williams \& Wilkins; 1999

7 Ottosson UB, Carlstrom K, Damber JE et al. Serum levels of progesterone and some of its metabolites including deoxycorticosterone after oral and parenteral administration. Br J Obstet Gynecol 1984; 91: 11111119

8 Di Lignieres B, Dennerstein L, Backstrom T. Influence of route of administration on progesterone metabolism. Maturitas 1995; 21: 251-257

9 Andréen L, Spigset 0 , Andersson A et al. Pharmacokinetics of progesterone and its metabolites allopregnanolone and pregnanolone after oral administration of low-dose progesterone. Maturitas 2006; 54: 238244

10 Birziece V, Bäckström T, Johansson IM et al. Neuroactive steroid effects on cognitive functions with a focus on the serotonin and GABA systems. Brain Res Rev 2006; 51: 212-239

11 Paszkowski $T$. Renaissance of the clinical applications of a progesterone. Gin Politec Project 2011; 19: 41-47

12 Maxson WS, Hargrove JT. Bioavailability of oral micronized progesterone. Fertil Steril 1985; 5: 622-626

13 Situr-Ware R, Bricairec C, De Lignieres $B$ et al. Oral micronized progesterone. Contraception 1987; 36: 373-402 
14 Simon J, Robinson DE, Andrews MC et al. The absorption of oral micronized progesterone: the effect of food, dose proportionality and comparison with intramuscular progesterone. Fertil Steril 1993; 60: 26-33

15 Barbieri RL. The endocrinology of the menstrual cycle. Methods Mol Biol 2014; 1154: 145-169

16 Tapia-Pizarro A, Figueroa P, Brito J et al. Endometrial gene expression reveals compromised progesterone signaling in women refractory to embryo implantation. Reprod Biol Endocrinol 2014; 12: 92

17 Lessey BA, Young SL. Homeostasis imbalance in the endometrium of women with implantation defects: the role of estrogen and progesterone. Semin Reprod Med 2014; 32: 365-375

18 Spencer TE, Bazer FW. Biology of progesterone action during pregnancy recognition and maintenance of pregnancy. Front Biosci 2002; 7: d1879-d1898

19 Garfield RE, Shi L, Shi SQ. Use of progesterone and progestin analogs for inhibition of preterm birth and other uterine contractility disorders. Facts Views Vis Obgyn 2012; 4: 237-244

20 Gáspár R, Ducza E, Mihálvi A et al. Pregnancy-induced decrease in the relaxant effect of terbutaline in the late-pregnant rat myometrium: role of G-protein activation and progesterone. Reproduction 2005; 130: 113-122

21 Gálik M, Gáspár R, Kolarovszki-Sipiczki Z et al. Gestagen treatment enhances the tocolytic effect of salmeterol in hormone-induced preterm labor in the rat in vivo. Am J Obstet Gynecol 2008; 198: 319.e1-319.e5

22 Kowalewski MP, Beceriklisoy HB, Asla S et al. Time related changes in luteal prostaglandin synthesis and steroidogenic capacity during pregnancy, normal and antiprogestin induced luteolysis in the bitch. Anim Reprod Sci 2009; 116: 129-138

23 Haslam SZ. Experimental mouse model of hormonal therapy effects on the postmenopausal mammary gland. Breast Dis 2005; 24: 71-78

24 Cline JM, Wood CE. Hormonal effects on the mammary gland of postmenopausal nonhuman primates. Breast Dis 2005-2006; 24: 59-70

25 Lactation. Bull World Health Organ 1989; 67 (Suppl.): 19-40

26 CheckJH. Premature ovarian insufficiency - fertility challenge. Minerva Ginecol 2014; 66: 133-153

27 Practice Committee of the American Society for Reproductive Medicine. The clinical relevance of luteal phase deficiency: a committee opinion. Fertil Steril 2012; 98: 1112-1117

28 Moberg C, Bourlev V, Ilyasova $N$ et al. Levels of ostrogen receptor, progesterone receptor and $\alpha \mathrm{B}$-crystallin in eutopic endometrium in relation to pregnancy in women with endometriosis. Hum Fertil (Camb) 2014; 19: 1-8; [Epub ahead of print]

29 Narin R, Nazik H, Aytan $H$ et al. Effects of natural progesterone on endometriosis in an experimental rat model: is it effective? Clin Exp Obstet Gynecol 2014; 41: 455-459

30 Pasqualini JR. Progestins in the menopause in healthy women and breast cancer patients. Maturitas 2009; 62: 343-348

31 Ziomkiewicz A, Pawlowski B, Ellison PT et al. Higher luteal progesterone is associated with low levels of premenstrual aggressive behavior and fatigue. Biol Psychol 2012; 91: 376-382

32 Vaisbuch E, de Ziegler D, Leong $M$ et al. Luteal-phase support in assisted reproduction treatment: real-life practices reported worldwide by an updated website-based survey. Reprod Biomed Online 2014; 28: 330 335

33 Arredondo F, Noble LS. Endocrinology of recurrent pregnancy loss. Semin Reprod Med 2006; 24: 33-39

34 The Writing Group for the PEPI Trial. Effects of hormone replacement therapy on endometrial histology in postmenopausal woman. The postmenopausal estrogen/progestin interventions (PEPI) trial. JAMA 1996; 275: 370-375

35 Fitzpatrick LA, Pace C, Wiita B. Comparison of regimens containing oral micronized progesterone or medroxyprogesterone acetate on quality of life in postmenopausal woman: a cross-sectional study. J Women's Health Gender-based Med 2000; 9: 381-387

36 Ryan N, Rosner A. Quality of life and costs associated with micronized progesterone and medroxyprogesterone acetate in hormone replacement therapy for nonhysterectomized, postmenopausal women. Clin Ther 2001; 23: 1099-1115

37 Cummings JA, Brizendine L. Comparison of physical and emotional side effects of progesterone or medroxyprogesterone in early postmenopausal women. Menopause 2002; 9: 254-263

38 Schindler AE. Einsatz von Gestagenen in der Schwangerschaft. Therapeutische und präventive Anwendungsmöglichkeiten. Frauenarzt 2005; 46: 586-589
39 Malet C, Spritzer P, Guillaumin D et al. Progesterone effect on cell growth, ultrastructural aspect and estradiol receptors of normal human breast epithelial (HABE) cells in culture. J Steroid Biochem Mol Biol 2000; 73: 1319-1330

40 Groshong SD, Owen GI, Grimison B et al. Biphasic regulation of breast cancer cell growth by progesterone: role of the cyclin-dependent kinase inhibitors, p21 and p27(Kip1). Mol Endocrinol 1997; 11: 15931607

41 Soderqvist G, von Schoultz B, Tani E et al. Estrogen and progesterone receptor content in breast epithelial cells from healthy women during the menstrual cycle. Am J Obstet Gynecol 1993; 168: 874-879

42 De Lignieres $B$. Effects of progestogens on the postmenopausal breast. Climacteric 2002; 5: 229-235

43 Foidart JM, Colin C, Denoo X et al. Estradiol and progesterone regulate the proliferation of human breast epithelial cells. Fertil Steril 1998; 69: 963-969

44 Formby B, Wiley TS. Bcl-2, surviving and variat CD44 v7-vlO are downregulated and $\mathrm{p} 53$ is upregulated in breast cancer cells by progesterone: inhibition of cell growth and induction of apoptosis. Mol Cell Biochem 1999; 202: 53-61

45 Lorrain J, Lalumiere LG, Caron P. The effects of oral micronized progesterone on bleeding patterns, endometrial histology and bone density in postmenopausal woman on hormone replacement therapy. Int J Gynaecol Obstet 1994; 46: 77-79

46 Pélissier $C$, Maroni $M$, Yaneva $H$ et al. Chlormadinone acetate versus micronized progesterone in the sequential combined hormone replacement therapy of the menopause. Maturitas 2001; 40: 85-94

47 Göretzlehner G, Lauritzen C, Römer T, Rossmanith W. Praktische Hormontherapie in der Gynäkologie. 6. Aufl. Berlin: De Gruyter; 2011: 44

48 Writing Group for the Women's Health Initiative Investigators. Risks and benefits of estrogen and progestin in healthy postmenopausal women. Principal results from the Women's Health Initiative Randomized Controlled Trial. JAMA 2002; 288: 321-333

49 Million Women Study Collaborators. Breast cancer and hormone replacement in the Million Women Study. Lancet 2003; 362: 419-427

50 Rajkumar L, Canada A, Esparza D et al. Decreasing hormonal protection is key to breast cancer prevention. Endocrine 2009; 35: 220-226

51 Seeger $H$, Wallwiener $D$, Mueck $A O$. The effect of progesterone and synthetic progestins on serum- and estradiol-stimulated proliferation of human breast cancer cells. Horm Metab Res 2003; 35: 76-80

52 Franke HR, Vermes I. Differential effects of progestogens on breast cancer cell lines. Maturitas 2003; 46 (Suppl. 1): 555-558

53 Mueck AO, Seeger H, Wallwiener D. Comparison of the proliferative effects of estradiol and conjugated equine estrogens on human breast cancer cells and impact of continuous combined progestogen addition. Climacteric 2003; 6: 221-227

54 Otto C, Fuchs I, Vonk R et al. Comparative analysis of the uterine and mammary gland effects of progesterone and medroxyprogesterone acetate. Maturitas 2010; 65: 386-391

55 Murkes D, Conner P, Leifland $K$. Effects of percutaneous estradiol-oral progesterone versus oral conjugated equine estrogens-medroxyprogesterone acetate on breast cell proliferation and bcl-2 protein in healthy women. Fertil Steril 2011; 95: 1188-1191

56 Boyd NF, Guo H, Martin LJ et al. Mammographic density and the risk and reduction of breast cancer. N Engl J Med 2007; 356: 227-236

57 Heusinger $K$, Loehberg CR, Haeberle L et al. Mammographic density as a risk factor for breast cancer in a German case-control study. Eur J Cancer Prev 2011; 20: 1-8

58 Boyd NF, Melnichouk O, Martin LJ et al. Mammographic density, response to hormones, and breast cancer risk. J Clin Oncol 2011; 29: 2985-2992

59 Carmona-Sánchez E, Cuadros López JL, Cuadros Celerrio ÁM et al. Assessment of mammographic density in postmenopausal women during long term hormone replacement therapy. Gynecol Endocrinol 2013; 29: $1067-1070$

60 Brand JS, Czene K, Erikson $L$ et al. Influence of lifestyle factors on mammographic density in postmenopausal women. PLoS One 2013; 8: e81876

61 Chen WY, Colditz GA, Rosner B et al. Use of postmenopausal hormones, alcohol, and risk for invasive breast cancer. Ann Intern Med 2002; 137: 798-804 
62 Kanaya AM, Herrington D, Vittinghoff $E$ et al. Heart and Estrogen/progestin Replacement Study: Glycemic effects of postmenopausal hormone therapy: the Heart and Estrogen/progestin Replacement Study. A randomized, doubled-blind, placebo-controlled trial. Ann Intern Med 2003; 138: 1-9

63 Fournier A, Berrino F, Clavel-Chapelon F. Unequal risks for breast cancer associated with different hormone replacement therapies: results from the E3N cohort study. Breast Cancer Res Treat 2008; 107: 103111

64 Writing Group for the PEPI Trial. Effects of estrogen or estrogen/progestin regimes on heart disease. Risks factors in postmenopausal women. JAMA 1995; 273: 199-208

65 Saarikoski S, Yliskoski M, Penttilä I. Sequential use of norethisterone and natural progesterone in pre-menopausal bleeding disorders. Maturitas 1990; 12: 89-97

66 Freeman E, Rickels K, Sondheimer SJ et al. A double-blind trial of oral progesterone, alprazolam and placebo in treatment of severe premenstrual syndrome. JAMA 1995; 274: 51-57
67 Dennerstein L, Spencer Gardner C, Gotts G et al. Progesterone and the premenstrual syndrome: a double-blind crossover trial. Br Med J 1985; 290: 1617-1621

68 Freeman $E W$, Weinstock L, Rickels $K$ et al. A placebo-controlled study of effects of oral progesterone on performance and mood. Br J Clin Pharmacol 1992; 33: 293-298

69 Schumacher M, Guennoun R, Ghoumari A et al. Novel perspectives for progesterone in hormone replacement therapy, with special reference to the nervous system. Endocr Rev 2007; 28: 387-439

70 Eser D, Schüle C, Baghai TC et al. Neuroactive steroids and affective disorders. Pharmacol Biochem Behav 2006; 84: 656-666

71 Herzog AG. Reproductive endocrine considerations and hormonal therapy for women with epilepsy. Epilepsia 1991; 32: 527-533

72 Wharton W, Gleason CE, Miller VM et al. Rationale and design of the Kronos Early Estrogen Prevention Study (KEEPS) and the KEEPS cognitive and affective sub study (KEEPS Cog). Brain Res 2013; 1514: 12-17

73 Schindler AE, Campagnoli C, Druckmann R et al. Classification and pharmacology of progestins. Maturitas 2003; 46: 7-16 